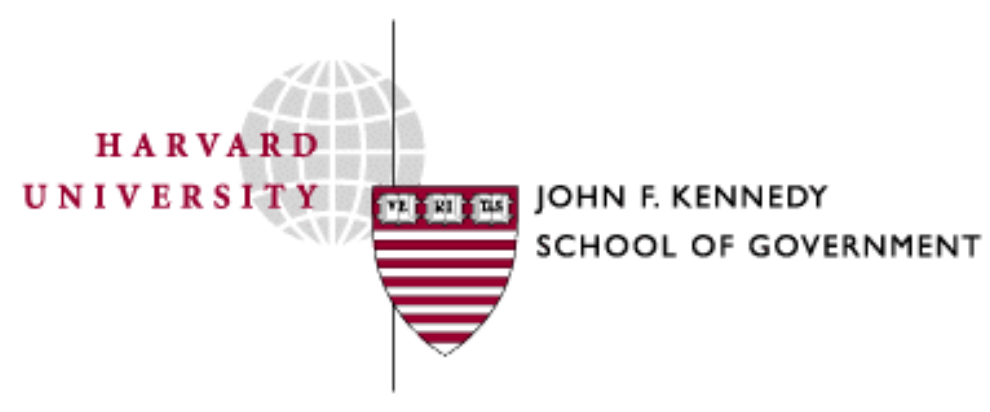

Faculty Research Working Papers Series

\title{
Two Simple Mechanisms for Advancing the Democratic Governance of Hong Kong
}

\author{
Thomas S. Axworthy \\ Centre for the Study of Democracy - Queen's University \\ Herman B. Leonard \\ John F. Kennedy School of Government - Harvard University
}

August 2006

RWP06-034

The views expressed in the KSG Faculty Research Working Paper Series are those of the author(s) and do not necessarily reflect those of the John F. Kennedy School of Government or Harvard University. Copyright belongs to the author(s). Papers may be downloaded for personal use only. 


\section{Two Simple Mechanisms for Advancing the Democratic Governance of Hong Kong}

In recent discussions in Hong Kong, we outlined two suggestions for increasing the governance role that might be given to parties that successfully develop an electoral mandate.

Under the existing conditions in Hong Kong, the "parties" are mainly focused on (and present positions on) what we would describe as "meta-issues" - issues of governance structure or philosophy - rather than on substantive issues (like housing policy, immigration policy, and so on). The DAB espouses maintaining close alignment with Beijing; Democrats propound rapid movement toward universal suffrage. These "policies" are mainly about how Hong Kong should decide, rather than about what it should decide. In addition, a large fraction of organized political activity in Hong Kong is organized in opposition to the government and its policies. In parliamentary systems, by definition, the government of the day enjoys the electoral mandate of a majority of the parliament - it is by holding a majority of seats (or by forming a coalition that then constitutes a majority) that it becomes the government of the day. With Hong Kong's executive-led government system, by contrast, the government (without an independent electoral mandate) is supposed to provide policy leadership - in the face of political forces that have organized against it, and without mechanisms to develop or inspire countervailing political movements in its favor.

Under the existing system and arrangements, it is not difficult to understand why parties would form along these lines, choosing (1) to focus on meta-issues rather than substantive issues; and (2) to organize principally in opposition to the government. As the situation currently stands, parties have little to gain either by developing and announcing broad platforms on substantive issues or by supporting the executive government in individual issues or more broadly. They have much to lose, indeed, by announcing substantive positions: the supporters they have attracted to their meta-view may have diverse views about substantive policy matters, and might thus be divided by the announcement of a substantive platform, reducing support for the party that was garnered initially on the basis of the meta-issue.

In our view, Hong Kong needs to find a way to give its political parties a positive stake in the success of the sitting government and its policies. It needs to develop mechanisms that give those who successfully seek an electoral mandate an opportunity to influence substantive policies - thus providing a stake in the success of policies pursued by the government. Only then will parties have the incentive to develop substantive views and platforms - and only then will government policies be implemented in a climate where the organized political movements in the society are not all lined up against them. 
Since the government cannot develop its own party supporting its policies, it seems that the only way to have the organized political movements have a stake in the success of government policies is to have those policies guided by the party platforms - and the easiest and most direct way to do this is to draw people from political parties into the government, with the understanding that they will have the discretion to push policies in their area of responsibility in the direction favored by their party platforms. Giving them a role will mean that they will "own" the policies being pursued - and thus give them a stake in the success of those policies.

We suggest two ways in which, under current arrangements, parties could be encouraged to develop policy platforms and take responsibility for making their policies happen. The first approach would be to delegate more responsibility to District Councils, allowing the electoral process of selection of District Council members to carry more weight in policy direction. This could be achieved by having government follow a policy of deferring to the choices and decisions of District Councils. If more decisions and responsibilities can be moved toward the District Councils over time, this will increase the stakes in the electoral process, providing more that can be gained by parties that formulate policy positions, win votes, and are then able to deliver on their policy mandates - that is, for behaving responsibly and positively in favor of effective government action through policy formulation and implementation.

A second direct way to give parties a greater stake in government would be to have the Chief Executive pursue a general policy of identifying members of LegCo from parties that have built a substantial electoral following and that have announced substantive policy positions and appointing them to Principal Official positions in executive departments that are related to the policy positions they have taken to gain an electoral following. Thus, if a party develops a platform with education reform as a significant plank and generates substantial electoral support for it, the Chief Executive might appoint a member of LegCo from that party as a Principal Official with responsibility for the education portfolio. This direct approach may not be possible, however - under some interpretations of existing law, LegCo members cannot serve as executive officials. If that interpretation prevails, more or less the same effect can be achieved by having someone from the party who did not stand for election to LegCo be appointed to hold the executive portfolio. Thus, parties might announce and campaign on the basis of a package consisting of (a) a platform of substantive policy ideas and positions; (b) a set of candidates standing for election to District Councils and/or LegCo; and (c) a short list of potential Principal Official appointees that the party would nominate to the Chief Executive if the party wins a significant number of seats in the election.

If a party showed electoral strength, the Chief Executive (at his or her discretion) would consider the party's nominees for Principal Official positions. If the CE decided to appoint one (or more) of the party's nominees, the implicit bargain would be in both directions: the Principal Official would be understood to have some (though not unlimited) latitude to advance policies in his or her portfolio in the direction sought by the party, and the government as a whole would defer, to some reasonable extent, by acquiescing or supporting those policies (since they are understood to have an electoral 
mandate behind them). Similarly, the appointed Principal Officials - and, importantly, their same-party colleagues in LegCo - would be expected to defer to some reasonable degree to the government by supporting government policies and proposals in the other policy areas. This is what it means to "join" a government - that your view gets some (earned) discretion in the areas of policy most important to you (and in which you have developed an electoral mandate), but that you and your party are now honor-bound to provide some reasonable degree of general support to the other policies pursued by the government you have joined.

It would, obviously, be entirely up the Chief Executive and the party representatives whether to make these arrangements - both the appointments and the implicit corresponding agreements of mutual deference. If a party is unable to provide its more general support, then such a deal could not be struck. If a party, after making such a deal, failed to deliver its more general support, then the deal could be undone. But if it works for both the party and the wider government, then it could continue - and in that case two important aspects of democracy would have been achieved: (1) some policies would be being driven by people associated with a party platform that developed an electoral mandate on the basis of its policy positions, and which thus reflects the views of the electorate; and (2) political parties would come to have a positive stake in the success of government's policies (because they are in part their own).

In effect, this would amount to forming a coalition government, with the Chief Executive as the broker, and with some ministers appointed from parties and a number of ministers appointed by the CE not on the basis of their party allegiance (or their party's electoral success). Coalition governments can be uncomfortable as working arrangements - with different ministries advancing different kinds of policies, so that there is no unified philosophy integrating the work of all the departments. Uncomfortable as a collection of people with imperfectly aligned interests and views may be, we suspect it will be far preferable to a government that is fully unified, but opposed on every front by the organized political movements of the day.

Both of the approaches we have suggested involve a new (additional) role for the Chief Executive. The CE will now be involved not only in formulating government's policies directly, but also in negotiating what are, in effect, power-sharing arrangements with some of the successful electoral parties. All of this - how much to defer to District Councils, how much independence of policy making will be allowed to Principal Officials drawn from parties, how much general support for other government policies to expect (or require) in return - will be at the discretion of the Chief Executive (and the party officials accepting the agreements). But these arrangements will be voluntary, and to work they must work for all of those involved - so the norms of what level of independence, deference, and support are appropriate is something that will be worked out by the Chief Executive and those from the parties with whom he or she enters into these arrangements. If such norms can be worked out in a way that feels fair to all concerned, they would provide a way to build positive support for government policies. 
To help the parties develop the kinds of policy platforms that they will need to enter this fray successfully, they will need to have funds to build their policy expertise. One way to do this would be to provide them with research funding (or help them find people who would support their research). Another would be to encourage them to develop relationships with like-minded parties outside Hong Kong, so that they can learn about the process of policy development and discourse from others elsewhere who have faced some similar challenges. Developing parties with a keen sense of what their constituents want - and the practical knowledge of policy design and the challenges of innovation will contribute greatly to their acting more responsibly in general. And giving the (thus better informed and prepared) parties that run successful electoral campaigns a stake in the overall government's success should gradually bring them around to playing a generally more positive role, able to affect policy by working with and within the government, rather than playing a purely nihilistic role.

The additional challenge that Hong Kong must face is the development of a sufficiently broad, deep, skilled, and experienced pool of people who appreciate and are willing to participate in political engagement and discourse. As a result of its history, many of the people with greatest interest in and experience in dealing with governmental affairs have chosen the route of serving in the civil service. This implies that many highly qualified people who could play a constructive role in political activity currently do not see that as their interest - and are serving in roles that make joining the political fray inappropriate. As Hong Kong reconsiders the role of senior civil servants (who previously handled both political and technical issues), dividing out the political matters to be handled by Principal Officials and their exempt staff, the role of senior civil servants will change, and some may decide to follow career tracks into politics. Given their historical dedication to non-partisanship, however, it is unlikely that many will choose this course. Consequently, Hong Kong needs to find ways to develop the substantive experience and political skills of others who are willing to take up the work of political engagement.

Executive-led government will only be sustainable, in the long run, when the policies it advances are broadly supported by the organized political forces in the society. For this to happen, there must be people both available to do, and skilled at doing, the work of organizing and orchestrating the political currents in the society - and the people who organize and harness those forces must have a role in determining government policies and actions, for only then will they support them as their own. They will then have a positive stake in the success of the governmental enterprise - a government enterprise which will then possess new momentum, legitimacy, and durability. 